\title{
Isocubanite, a new definition of the cubic polymorph of cubanite $\mathrm{CuFe}_{2} \mathrm{~S}_{3}$
}

\author{
René Caye*, Bernard Cervelle†, Fabien Cesbronł, Elisabeth Oudin*, \\ Paul Picot*, and François Pillard* \\ * Bureau de Recherches Géologiques et Minières, Département MGA, Boite Postale 6009, \\ 45060 Orléans Cedex, France \\ $\uparrow$ Laboratoire de Minéralogie-Cristallographie associé au CNRS, Université P. et M. Curie, \\ Tour 16, 4 place Jussieu, 75252 Paris Cedex 05, France \\ \$ Laboratoire d'Etude des Matériaux Minéraux, U.F.R. Faculté des Sciences, Université d'Orléans, \\ 45067 Orléans Cedex 2, France
}

\begin{abstract}
Isocubanite is a cubic polymorph of cubanite $\mathrm{CuFe}_{2} \mathrm{~S}_{3}$, discovered in the submarine sulphide deposits of the East Pacific Rise (EPR) and the Red Sea, in association with chalcopyrite, pyrrhotine, pyrite, sphalerite or wurtzite and anhydrite. It was previously obtained artificially and mentioned as iss, intermediate solid solution of $\mathrm{CuFe}_{2} \mathrm{~S}_{3}$ composition'. Crystals are cubic with $a=5.303(3) \AA$ and strongest lines in the X-ray powder pattern are 3.059 (10) $111,1.876(7) 220,1.602$ (5) 311 . Euhedral grains range from a few microns up to $400 \mu \mathrm{m}$, with a Vickers microhardness of $175(25) \mathrm{kg} / \mathrm{mm}^{2}$ for $\mathrm{P}=100 \mathrm{~g}$. Isocubanite is usually intimately intergrown with iron- and zinc-rich chalcopyrite and is opaque with a metallic lustre and a bronze colour. Pinkish brown and isotropic in polished sections; reflectance values (SiC standard) are: 420

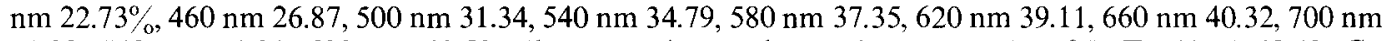
$41.33,740 \mathrm{~nm} 41.91,780 \mathrm{~nm} 42.50$. Electron microprobe analyses gave (wt. \%): $\mathrm{Fe} \mathrm{41.64-42.49,} \mathrm{Cu}$ 20.79-21.52, $\mathrm{Zn} 0.77-1.09, \mathrm{~S} 35.49-35.82$, corresponding to the formula $(\mathrm{Cu}, \mathrm{Zn}) \mathrm{Fe}_{2} \mathrm{~S}_{3}$.

Isocubanite is characteristic of high-temperature $\left(>200^{\circ} \mathrm{C}\right)$ present-day submarine sulphide deposits where hot hydrothermal fluids are quenched by seawater as in EPR deposits or by cooler brines as in Atlantis II Deep, in the Red Sea; it is unstable and therefore unusual in fossil ores. This cubic phase was previously observed and described more or less accurately as cubic cubanite, cubanite $I I$, chalcopyrrhotite and iss; the name isocubanite, proposed in order to clarify the nomenclature, and this new description, were approved by the IMA Commission on New Minerals and Mineral Names.
\end{abstract}

KeYwords: isocubanite, cubanite, new mineral, East Pacific Rise, Red Sea.

\section{Introduction}

DURING a study of present-day submarine sulphide deposits, discovered in the East Pacific Rise (EPR $21^{\circ} \mathrm{N}$ ) and the Red Sea (Atlantis II Deep), a cubic polymorph of cubanite $\mathrm{CuFe}_{2} \mathrm{~S}_{3}$ has been observed in association with chalcopyrite, pyrrhotine, pyrite, sphalerite or wurtzite and anhydrite (Noltner, 1979; Picot et al., 1980; Haymon and Kastner, 1981; Styrt et al., 1981; Oudin, 1981, 1983a; Pottorf and Barnes, 1983; Lafitte and Maury, 1983; Koski et al., 1984; Zierenberg et al., 1984; Oudin et al., 1984; Lafitte et al., 1984).

This polymorph can be obtained artificially by heating orthorhombic cubanite between 200 and $270^{\circ} \mathrm{C}$ (Cabri et al., 1973; Fleet, 1970; Sawada et al.,
1962; Yund and Kullerud, 1961). It is frequently mentioned in the literature as iss, "intermediate solid solution of $\mathrm{CuFe}_{2} \mathrm{~S}_{3}$ composition' (Amcoff, 1981; Barton, 1973; Cabri, 1973; Kojima and Sugaki, 1984; Sugaki et al., 1975).

It was apparently first reported by Ramdohr (1928) and then by Odman (1933) under the name of cubanite II. Later, Genkin et al. (1965) almost certainly recorded this phase in the ores of the Noril'sk and Talnakh deposits, as fine rims on the periphery of orthorhombic cubanite. The minerals were not analysed, but X-ray data and reflectivities show they are identical with the East Pacific Rise and the Red Sea cubic polymorph of cubanite.

The name chalcopyrrhotit was first used by Blomstrand (1870) for a material proved later to be 


\begin{tabular}{|c|c|c|c|c|c|c|c|c|}
\hline \multicolumn{3}{|c|}{1} & \multicolumn{2}{|c|}{2} & \multicolumn{2}{|c|}{3} & \multicolumn{2}{|c|}{4} \\
\hline$u_{0}$ & $d_{\mathrm{obs}}$ & $d_{\mathrm{calc}}$ & $\mathrm{I} / \mathrm{I}$ 。 & $d_{\mathrm{obs}}$ & $\mathrm{I} / \mathrm{I}_{0}$ & $d_{\mathrm{obs}}$ & $\mathrm{I} / \mathrm{I}_{0}$ & $d_{\mathrm{obs}}$ \\
\hline 10 & 3.059 & 3.062 & 10 & 3.061 & 10 & 3.052 & 10 & 3.049 \\
\hline 2 & 2.647 & 2.652 & 3 & 2.655 & 4 & 2.643 & 3 & 2.640 \\
\hline 7 & 1.876 & 1.875 & 8 & 1.881 & 8 & 1.867 & 8 & 1.867 \\
\hline \multirow[t]{2}{*}{5} & 1.602 & 1.599 & 7 & 1.602 & 7 & 1.594 & 7 & 1.594 \\
\hline & & & 1 & 1.536 & $1 \mathbf{b}$ & 1.526 & 1 & 1.524 \\
\hline \multirow[t]{2}{*}{2} & 1.327 & 1.326 & 3 & 1.328 & 4 & 1.321 & 1 & 1.321 \\
\hline & $5.303(3)$ & & \multicolumn{2}{|c|}{5.31} & \multicolumn{2}{|c|}{$5.286(1)$} & \multicolumn{2}{|c|}{$5.283(1)$} \\
\hline
\end{tabular}

1 - Isocubanite from $\operatorname{EPR}\left(21^{\circ} \mathrm{N}\right)$; present study.

2 - Isocubanite from Norilsk (Genkin et al., 1965).

3- Artificial isocubanite (Cabri et al., 1973 ).

4- Artificial isocubanite (MacLean et al., 1972).

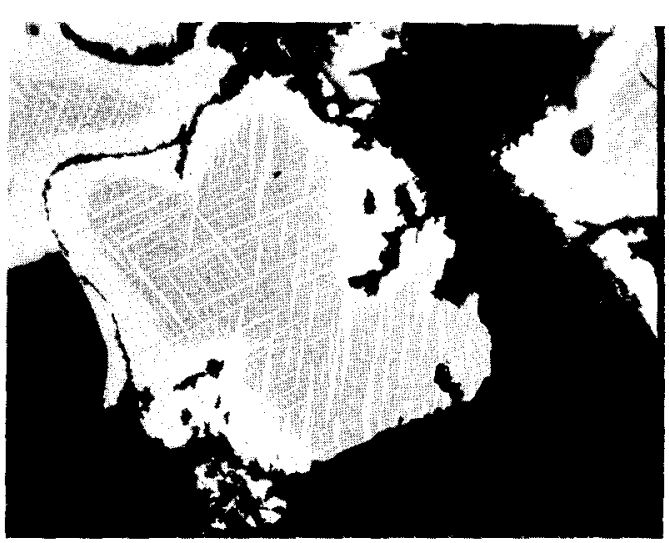

FIG. 1. Isocubanite (medium grey) with lamellae and rim of $\mathrm{Fe}-\mathrm{Zn}$-rich chalcopyrite, associated with wurtzite in EPR $21^{\circ} \mathrm{N}$ sample. Polished section photograph $(\times 120)$.

cubanite by Geijer (1924) and then discredited; a study of the topotype material by the Department of Mineralogy of the British Museum (Natural History) also proved that it was a mixture without isotropic material (M. H. Hey, pers. comm.). Unfortunately, Borchert (1934), observing that cubanite $I I$ was a mixture of thin lamellae of chalcopyrite in an isotropic phase close to cubanite, named this material chalcopyrrhotite. This name was later used by Ramdohr (1960) for several occurrences of this phase, although he thought that the choice of the name was unfortunate. In submarine sulphide samples, this mineral has variously been called chalcopyrrhotite, iss, cubic cubanite or even (incorrectly) cubanite.

In order to clarify the nomenclature, it is therefore proposed that this cubic polymorph of cubanite be named isocubanite as it is not a constituent of Blomstrand's chalcopyrrhotit but identical to Genkin's cubic cubanite. This name was approved before publication by the Commission on New Names and Mineral Names of the International Mineralogical Association.

\section{Crystallographic properties}

A homogeneous fragment, free of chalcopyrite lamellae or rims, from an East Pacific Rise $21^{\circ} \mathrm{N}$ 'black smoker' chimney, was selected under the microscope and oriented with a precession camera using Mo- $K \alpha$ radiation. Isocubanite is cubic $F m 3 m$ with $a=5.303(3) \AA$. No reflections from chalcopyrite were observed (Cabri et al., 1973).

An X-ray powder diagram was obtained using a $114.6 \mathrm{~mm}$ diameter Gandolfi camera and $\mathrm{Fe}-K \alpha$ radiation; data are presented in Table 1, along with those from Noril'sk isocubanite and from cubic cubanites obtained by heating and quenching orthorhombic cubanites.

It can be seen from this table that the $d_{h k l}$ and $a$ parameters of artificial isocubanites are systematically smaller than for natural isocubanites. As for East Pacific Rise isocubanite, this could be related to small amounts of zinc (ionic radius: $0.60 \AA$ ) replacing copper (ionic radius: $0.57 \AA$ ) (Oudin, 1981). The X-ray pattern is also very close to that of cubic chalcopyrite (Genkin et al., 1965).

\section{Physical properties}

Pure isocubanite (i.e. devoid of chalcopyrite inclusions) is very rarely observed; it is usually intimately intergrown with iron- and zinc-rich chalcopyrite which appears as lamellae and/or rims (Fig. 1); both textures can be interpreted as due to 
TABLE 2. Reflectivities (\%) of isocubanite in air and oil

\begin{tabular}{lccccc}
\hline$\lambda_{\text {nm }}$ & air & oil & $\lambda_{\text {nm }}$ & air & oil \\
\hline & & & & & \\
420 & 22.73 & 12.94 & 620 & 39.11 & 25.83 \\
440 & 24.65 & 14.58 & 640 & 39.70 & 26.37 \\
460 & 26.87 & 16.40 & 660 & 40.32 & 26.80 \\
480 & 29.23 & 18.30 & 680 & 40.91 & 27.72 \\
500 & 31.34 & 20.08 & 700 & 41.33 & 27.48 \\
520 & 33.16 & 21.56 & 720 & 41.58 & 27.66 \\
540 & 34.79 & 22.73 & 740 & 41.91 & 27.87 \\
560 & 36.19 & 23.75 & 760 & 42.46 & 28.08 \\
580 & 37.35 & 24.58 & 780 & 42.50 & 27.42 \\
600 & 38.25 & 25.32 & 800 & 41.66 & 25.54
\end{tabular}

TABLE 3. Electron microprobe analyses (wt.\%) of isocubanite, in one sample from $E P R(21 \mathrm{~N})$, associated with pyrrhotine and wurtzite

\begin{tabular}{lrrrrr}
\hline $\mathrm{S}$ & 35.62 & 35.49 & 35.57 & 35.71 & 35.82 \\
$\mathrm{Fe}$ & 42.49 & 41.99 & 41.64 & 42.21 & 41.93 \\
$\mathrm{Zn}$ & 1.09 & 1.02 & 0.96 & 0.85 & 0.77 \\
$\mathrm{Cu}$ & 21.52 & 20.79 & 21.23 & 21.27 & 21.27 \\
& $\overline{100.72}$ & $\overline{99.29}$ & $\overline{99.40}$ & $\overline{100.04}$ & $\overline{99.78}$ \\
\hline
\end{tabular}

exsolution of chalcopyrite from isocubanite (see Brett, 1964). It is opaque with a metallic lustre and a bronze colour, usually as euhedral grains; cubooctahedra are frequently observed (Fig. 2); grain size varies from a few microns up to approximately $400 \mu \mathrm{m}$. The Vickers microhardness is $175(25)$ $\mathrm{kg} / \mathrm{mm}^{2}$ for $\mathrm{P}=100 \mathrm{~g}$.

In polished section, the mineral is pinkish-brown and, in direct contact with pyrrhotine, appears slightly browner and softer. It is isotropic and the reflectance values, measured in air and oil $(n=$ 1.5155 for $\lambda=589 \mathrm{~nm}$ ) using a prism monochromator and a SiC standard, are given in Table 2. The reflectivities are very different from those of chalcopyrite and pyrrhotine; they are close to $R_{\min }$ of cubanite, but this mineral is clearly anisotropic. Iron- and zinc-rich chalcopyrite associated with isocubanite has a lower reflectivity than normal chalcopyrite (Fig. 3).

\section{Chemical properties}

Isocubanite was analysed using a CAMEBAX electron microprobe, with $\mathrm{Cu}, \mathrm{ZnS}$ and $\mathrm{FeS}$ as standards; the results are presented in Table 3 . All the analyses show zinc contents ranging from 1.09 to $0.77 \mathrm{wt}$. \% within the same sample and the corresponding formulae, on the basis of three atoms of sulphur, are from $\mathrm{Cu}_{0.91} \mathrm{Fe}_{2.05} \mathrm{Zn}_{0.05} \mathrm{~S}_{3}$ to $\mathrm{Cu}_{0.90} \mathrm{Fe}_{2.02} \mathrm{Zn}_{0.03} \mathrm{~S}_{3}$. In East Pacific Rise samples, the isocubanite $\mathrm{Zn}$-content varies from nil up to approximately $1 \mathrm{wt} \%$. However, Red Sea isocubanite may contain up to $2 \mathrm{wt} \% \mathrm{Zn}$; moreover it has been proved experimentally that a significant amount of zinc can be accommodated in isocubanite (Wiggins and Craig, 1980; Kojima and Sugaki, 1985).

It has been suggested by Oudin (1981) that the $\mathrm{ZnS}$ content of isocubanite is temperature dependent in East Pacific Rise samples, as shown by the experimental work of Hutchison and Scott (1981) who studied the solubility of $\mathrm{ZnS}$ in iss coexisting with pyrite and pyrrhotine, in the $\mathrm{Cu}-\mathrm{Fe}-\mathrm{Zn}-\mathrm{S}$ system at high temperature.

Temperature estimates using the $\mathrm{ZnS}$ content of EPR $21^{\circ} \mathrm{N}$ isocubanite (associated with wurtzite and pyrrhotine), extrapolated to lower temperatures, are close to the measured exit temperature of the hydrothermal fluids (Scott, 1983). Isocubanite forming the inner conduit of a chimney shows a decrease in $\mathrm{Zn}$ content towards the chimney centre (from 0.8 to 0.5 wt. \%). However, isocubanite is not buffered by zinc- and iron sulphides and temperature cannot be estimated (S. Scott, pers. comm.).

Iron-rich chalcopyrite associated with isocubanite also contains zinc (up to $2 \mathrm{wt} \%$ ) which may explain the variations from stoichiometric composition observed when plotted on the $\mathrm{Cu}$ Fe-S diagram of Lafitte and Maury (1983). Up to 0.04 wt. $\%$ selenium has been analysed in some Red

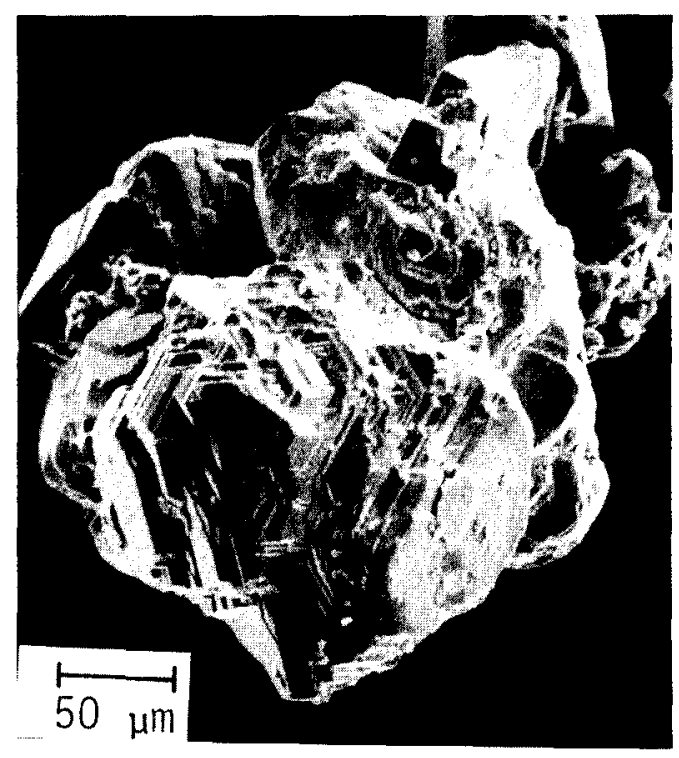

FIG. 2. Aggregate of idiomorphic grains of isocubanite associated with minor pyrite (P). SEM photograph. 


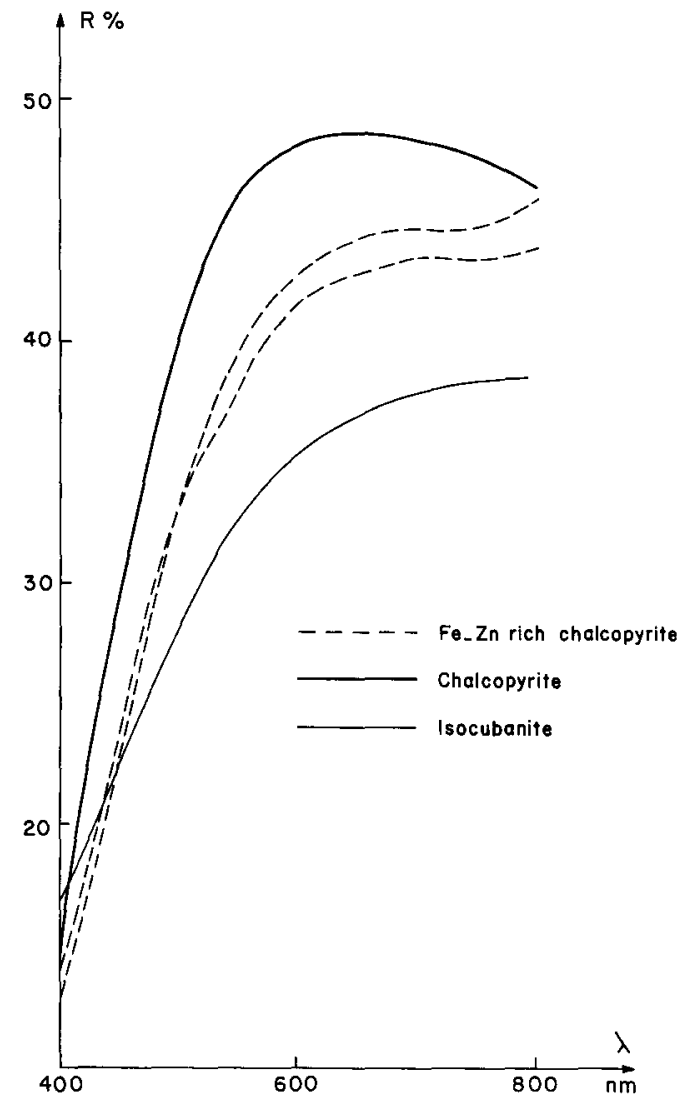

FIG. 3. Reflectivity of isocubanite and associated $\mathrm{Fe}-\mathrm{Zn}$ rich chalcopyrite, as compared with chalcopyrite.

Sea isocubanites (Oudin, 1987). Nickel was also sought but not detected.

\section{Occurrence and stability in ore deposits}

Isocubanite is an unstable phase and therefore unusual in fossil ores. It was described by Ramdohr (1960) in numerous contact metasomatic deposits, sometimes in deposits metamorphosed by lava flows, or in stony meteorites.

Isocubanite is characteristic of high-temperature $\left(>200{ }^{\circ} \mathrm{C}\right)$ present-day submarine sulphide deposits (Oudin, 1983b). Quenching by seawater (East Pacific Rise) or cooler brines and sediments in the Atlantis II Deep (Red Sea) and the presence of minor amounts of zinc probably prevents an early breakdown of the mineral. However, in fossil analogues of East Pacific Rise deposits, such as massive sulphides from Cyprus or Oman, isocubanite has not been identified; but lattice textures in chalcopyrite, outlined by dissolution or by a network of microcrystalline pyrite in Oman samples, have been interpreted as ghost textures of isocubanite-chalcopyrite intergrowths (Lescuyer et al., in press). This interpretation is supported by observations in Red Sea samples from the presently accumulating hydrothermal sediments of Atlantis II Deep, of partly destabilized isocubanitechalcopyrite grains displaying a lattice texture outlined by minute pyrite inclusions associated with other destabilization products (Oudin, in prep.). A similar interpretation has been given by Ixer et al. (1984) for minute inclusions of associated chalcopyrite-pyrrhotine or chalcopyrite-cubanite in pyrite from Oman, which have also been observed in modern samples from the Galapagos Ridge (Oudin, 1982).

$\mathrm{Zn}$-bearing isocubanite is most probably replaced by chalcopyrite containing minute starshaped exsolutions of sphalerite (Oudin and Constantinou, 1984; Sugaki et al., 1987) in fossil ores.

\section{Conclusions}

The cubic polymorph of cubanite $\mathrm{CuFe}_{2} \mathrm{~S}_{3}$ has rarely been identified in fossil ores; it is referred in the literature under several names including cubanite II, cubic cubanite, chalcopyrrhotite and iss (intermediate solid solution). Its occurrence in modern submarine mineralizations made a new definition and description of its crystallographic and chemical properties desirable. The name isocubanite is given in order to avoid the confusion arising from the use of several different names, sometimes covering mixtures or badly defined products. Type material will be deposited in the Mineralogical Collection of the Ecole Nationale Supérieure des Mines, Paris.

\section{Acknowledgements}

We are indebted to R. Hekinian, from IFREMER, who gave us the first sulphide samples dredged on the East Pacific Rise, and to the Saudi Sudanese Red Sea Commission for authorization to work on Atlantis II cores. We are also grateful to P. G. Embrey who suggested the name isocubanite and helped to improve this manuscript.

\section{References}

Amcoff, Ö. (1981) Heating experiments of chalcopyrite pyrrhotite ores: studies on the stability of the intermediate solid solution. Neues Jahrb. Mineral., Mh. $553-68$

Barton, P. B. Jr (1973) Solid solutions in the system $\mathrm{Cu}-\mathrm{Fe}-\mathrm{S}$. Part I: the $\mathrm{Cu}-\mathrm{S}$ and $\mathrm{Cu}-\mathrm{Fe}-\mathrm{S}$ joins. Econ. Geol. 68, 455-65. 
Blomstrand, C. W. (1870) On some new Swedish minerals and the composition of pyrrhotite. Ofvers. K. Vetensk. Akad. Forh. Stockh. 27, 19-27.

Borchert, H. (1934) Über Entmischungen im System $\mathrm{Cu}-\mathrm{Fe}-\mathrm{S}$ und ihre Bedeutung als geologische Thermometer. Chem. Erde, 9, 145-72.

Brett, R. (1964) Experimental data from the system $\mathrm{Cu}-\mathrm{Fe}-\mathrm{S}$ and their bearing on exsolution textures in ores. Econ. Geol. 59, 1241-69.

Cabri, L. J. (1973) New data on phase relations in the $\mathrm{Cu}-\mathrm{Fe}-\mathrm{S}$ system. Ibid. 68, $443-54$.

- Hall, S. R., Szymanski, J. T., and Stewart, J. M. (1973) On the transformation of cubanite. Can. Mineral. 12 , 33-8.

Fleet, M. E. (1970) Refinement of the crystal structure of cubanite and polymorphism of $\mathrm{CuFe}_{2} \mathrm{~S}_{3} . Z$. Kristallogr. 132, $276-87$.

Geijer, P. (1924) On cubanite and 'chalcopyrrhotite' from Kaveltorp. Geol. Fören. Stockh. Förh. 46, 354-5.

Genkin, A. D., Filimonova, A. A., Shadlun, T. N., Soboleva, S. V., and Troneva, N. V. (1965) On cubic cubanite and cubic chalcopyrite. Geochim. Internat. 2 , $766-81$

Haymon, R. and Kastner, M. (1981) Hot spring deposits on the East Pacific Rise at $21^{\circ} \mathrm{N}$.: preliminary description of mineralogy and genesis. Earth Planet. Sci. Lett. 53, 363-81.

Hutchison, M. N. and Scott, S. D. (1981) Sphalerite geobarometry in the $\mathrm{Cu}-\mathrm{Fe}-\mathrm{Zn} \mathrm{S}$ system. Econ. Geol. 76, 143-53.

Ixer, R. A., Alabaster, I., and Pearce, J. A. (1984) Ore petrography and geochemistry of massive sulphide deposits within the semail ophiolite, Oman. Trans. Inst. Mining Metallurgy, 93, 114-24.

Kojima, S. and Sugaki, A. (1984) Phase relations in the central portions of the $\mathrm{Cu}-\mathrm{Fe}-\mathrm{Zn}-\mathrm{S}$ system between $800^{\circ}$ and $500^{\circ} \mathrm{C}$. Mineral. $J .12,15-28$.

(1985) Phase relations in the $\mathrm{Cu}-\mathrm{Fe}-\mathrm{Zn}-\mathrm{S}$ system between $500^{\circ}$ and $300^{\circ} \mathrm{C}$ under hydrotherma conditions. Econ. Geol. 80, $158 \cdot 71$.

Koski, R. A., Claque, D. A., and Oudin, E. (1984) Mineralogy and chemistry of massive sulphide deposits from the Juan de Fuca Ridge. Geol. Soc. Am. Bull. 95, 93045.

Lafitte, R. and Maury, R. (1983) The stoichiometry of sulfides and its evolution: a chemical study of pyrites, chalcopyrites and sphalerites from terrestrial and oceanic environments. Earth Planet. Sci. Lett. 64, $145-52$.

- Maury, R., and Perseil, E. A. (1984) Analyse minéralogique de cheminées à sulfures de la Dorsale Est Pacifique $\left(13^{\circ}\right.$ N.). Mineral. Deposita, 19, 274-82.

Lescuyer, J. L., Oudin, E., and Beurrier, M. (in press) Review of the different types of mineralization related to the Oman ophiolitic volcanism. Schweizerbach' Sche Verlagbuch Handlung. IAGOD Symposium 1986, 3.

Maclean, W. H., Cabri, L. J., and Gill, J. E. (1972) Exsolution products in heated chalcopyrite. Can. $J$ Earth Sci. 9, $1305-17$.

Noltner, J. (1979) Erzmicroskopische Untersuchungen an Erzschalämmen aus dem Atlantis II Tief, Roten Meer. Diplom. Arbeit, Universität Heidelberg.

Odman, O. H. (1933) Erz mikroskopische Untersuchung des Sulfiderze von Kaveltorp in Mittelsschweden. Geol. För. Förh. 55, H.4, no. 395

Oudin, E. (1981) Etudes minéralogique et géochimique des dépôts sulfurés sous-marins actuels de la ride Est-Pacifique $\left(21^{\circ}\right.$ N.). Document du BRGM, $\mathrm{n}^{\circ} 25,241$. (1982) Mineralogical study of hydrothermal sulphides collected in the Galapagos Rift at $0^{\circ} 45^{\prime}$ N. A comparison with other rift sulphides. Internal Report, BRGM 82 SGN 841 MGA.

(1983a) Hydrothermal sulphide deposits of the East Pacific Rise $\left(21^{\circ}\right.$ N.). Part I: Descriptive Mineralogy. Marine Mining, 4, 39-77.

(1983b) Minéralogie de gisements et indices liés à des zones d'accretion océaniques actuelles (Ride Est Pacifique et Mer Rouge) et fossile (Chypre). Chron. Rech. Min. 470, 43-56.

-(1987) Trace element and precious metals concentrations in East Pacific Rise, Cyprus and Red Sea submarine sulphide deposits. In Marine minerals. Advances in Research and Resource Assessment. Nato ASI Series, (P. G. Teleki, M. R. Dobson, J. R. Moore and U. von Stackelberg, eds.). D. Reidel Publisher, 349-62.

- and Constantinou, G. (1984) Black smoker chimney fragments in Cyprus sulphide deposits. Nature, 308, $349-53$.

- Thisse, Y., and Ramboz, C. (1984) Fluid inclusion and mineralogical evidence for high-temperature saline hydrothermal circulation in the Red Sea metalliferous sediments: Preliminary results. Marine Mining, 5, 3-31.

Picot, P. et al. (1980) Etude minéralogique d'échantillons du golfe de Californie, (Campagne CYAMEX). Document du BRGM $\mathrm{n}^{\circ} 20,50$.

Pottorf, R. J. and Barnes, H. L. (1983) Mineralogy, geochemistry and ore genesis of hydrothermal sediments from the Atlantis II Deep, Red Sea. Econ. Geol., Monograph 5, 198-223.

Ramdohr, P. (1928) Neue mikroskopische Beobachtungen am Cubanit (Chalmersit) und Üeberlegungen über seine lagerstättenkundliche Stellung. $Z$. prakt. Geol. 36, 169-78.

- (1960) Die Erzmineralien und ihre Verwachsungen. Akademie-Verlag, Berlin, 1960

Sawada, M., Ozima, M., and Fujiki, Y. (1962) Magnetic properties of cubanite (CuFeS). J. Geomag. Geoelect. 14, $107 \cdots 12$.

Scott, S. (1983) Chemical behaviour of sphalerite and arsenopyrite in hydrothermal and metamorphic environments. Mineral. Mag. 47, 427-35.

Styrt, M. M., Brackmann, A. J., Holland, H. D., Clark, B. C., Pisutha-Arnaud, V., Eldridge, C. S., and Ottomoto, H. (1981) Mineralogy and isotopic composition of sulfur in hydrothermal sulfide/sulfate deposits on the East-Pacific Rise, $21^{\circ}$ N. latitude. Earth Planet. Sci. Lett. 53, 382-90.

Sugaki, A., Shima, H., Kitakaze, A., and Harada, H. (1975) Isothermal phase relations in the system $\mathrm{Cu}-\mathrm{Fe}-\mathrm{S}$ under hydrothermal conditions at $350^{\circ} \mathrm{C}$ and $300^{\circ} \mathrm{C}$. Econ. Geol. 70, 806. 23.

-Kitakaze, A. C. L., and Kojima, S. (1987) Bulk compositions of intimate intergrowths of chalcopyrite and sphalerite and their genetic implications. Mineral. Deposita, 22, 26-36. 
Wiggins, L. B. and Craig, J. R. (1980) Reconnaissance of the $\mathrm{Cu}-\mathrm{Fe}-\mathrm{Zn}-\mathrm{S}$ system: sphalerite phase relationships. Econ. Geol. 75, 742-51.

Yund, R. A. and Kullerud, G. (1961) The system Cu-Fe-S. Carnegie Inst. Washington, Yearb. 60, 454-88.

Zierenberg, R. A., Shanks, W. C. III, Bischoff, J. L. (1984)
Massive sulphide deposits at $21^{\circ} \mathrm{N}$, East Pacific Rise: chemical composition, stable isotopes, and phase equilibria. Geol. Soc. Am. Bull. 95, 922-9.

[Manuscript received 12 June 1987; 